Prepared for the U.S. Department of Energy

under Contract DE-AC05-76RL01830

\title{
Radionuclide Retention in Concrete Wasteforms
}

CC Bovaird

DP Jansik
DM Wellman

MI Wood

September 2011
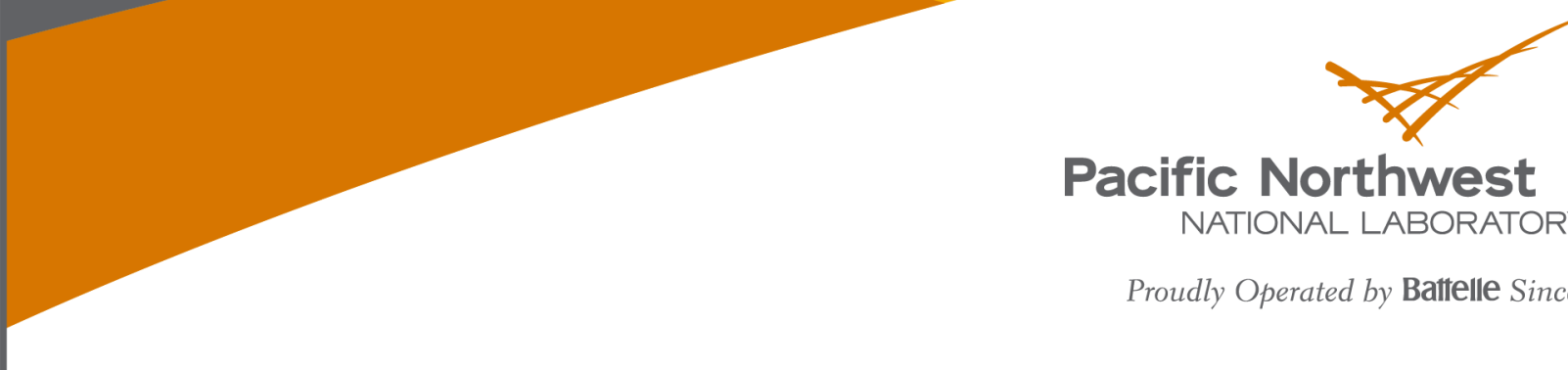

Pacific Northwest

NATIONAL LABORATORY

Proudly Operated by Battelle Since 1965 


\title{
DISCLAIMER
}

This report was prepared as an account of work sponsored by an agency of the United States Government. Neither the United States Government nor any agency thereof, nor Battelle Memorial Institute, nor any of their employees, makes any warranty, express or implied, or assumes any legal liability or responsibility for the accuracy, completeness, or usefulness of any information, apparatus, product, or process disclosed, or represents that its use would not infringe privately owned rights. Reference herein to any specific commercial product, process, or service by trade name, trademark, manufacturer, or otherwise does not necessarily constitute or imply its endorsement, recommendation, or favoring by the United States Government or any agency thereof, or Battelle Memorial Institute. The views and opinions of authors expressed herein do not necessarily state or reflect those of the United States Government or any agency thereof.

\author{
PACIFIC NORTHWEST NATIONAL LABORATORY \\ operated by \\ BATTELLE \\ for the \\ UNITED STATES DEPARTMENT OF ENERGY \\ under Contract DE-AC05-76RL01830
}

Printed in the United States of America
Available to DOE and DOE contractors from the Office of Scientific and Technical Information,
P.O. Box 62, Oak Ridge, TN 37831-0062;
ph: (865) 576-8401
fax: $(865)$ 576-5728
email: reports@adonis.osti.gov

\begin{abstract}
Available to the public from the National Technical Information Service, U.S. Department of Commerce, 5285 Port Royal Rd., Springfield, VA 22161 ph: (800) 553-6847 fax: $(703) 605-6900$ email: orders@ntis.fedworld.gov online ordering: http://www.ntis.gov/ordering.htm
\end{abstract}

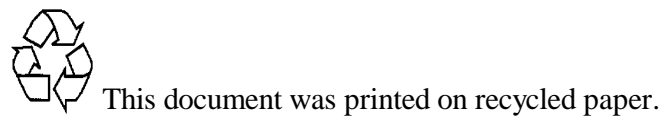




\section{Radionuclide Retention in Concrete Wasteforms}

CC Bovaird

DP Jansik

DM Wellman

MI Wood

September 2011

Prepared for

the U.S. Department of Energy

under Contract DE-AC05-76RL01830

Pacific Northwest National Laboratory

Richland, Washington 99352 



\section{Summary}

Assessing long-term performance of Category 3 waste cement grouts for radionuclide encasement requires knowledge of the radionuclide-cement interactions and mechanisms of retention (i.e., sorption or precipitation); the mechanism of contaminant release; the significance of contaminant release pathways; how wasteform performance is affected by the full range of environmental conditions within the disposal facility; the process of wasteform aging under conditions that are representative of processes occurring in response to changing environmental conditions within the disposal facility; the effect of wasteform aging on chemical, physical, and radiological properties; and the associated impact on contaminant release.

This knowledge will enable accurate prediction of radionuclide fate when the wasteforms come in contact with groundwater. The information present in the report provides data that 1) measures the effect of concrete wasteform properties likely to influence radionuclide migration; and 2) quantifies the rate of carbonation of concrete materials in a simulated vadose zone repository. 


\section{Acknowledgments}

Funding for this project was provided by CH2M HILL Plateau Remediation Company (Marc Wood). The authors thank Steven Baum and Keith Geizsler (Pacific Northwest National Laboratory) for conducting inductively coupled plasma optical emission spectrometry and inductively coupled plasmamass spectrometry analyses, respectively. 


\section{Acronyms and Abbreviations}

$\begin{array}{ll}\text { FY } & \text { fiscal year(s) } \\ \text { ICP-MS } & \text { inductively coupled plasma-mass spectrometry } \\ \text { ICP-OES } & \text { inductively coupled plasma-optical emission spectrometry } \\ \text { L } & \text { limestone } \\ \text { MC } & \text { moisture content } \\ \text { OPC } & \text { ordinary Portland cement } \\ \text { PUF } & \text { pressurized unsaturated flow } \\ \text { PVC } & \text { polyvinyl chloride } \\ \text { wt } & \text { weight } \\ \text { XMT } & \text { X-ray microtomography }\end{array}$





\section{Contents}

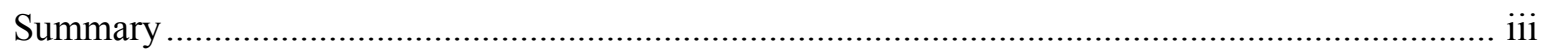

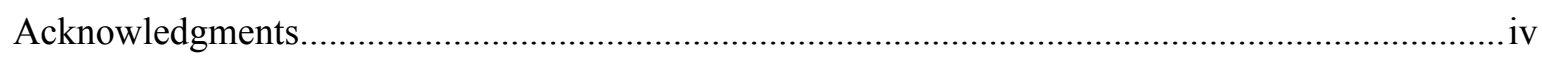

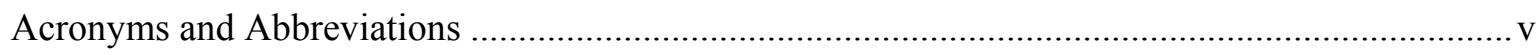

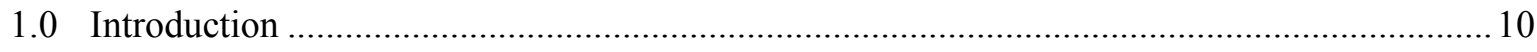

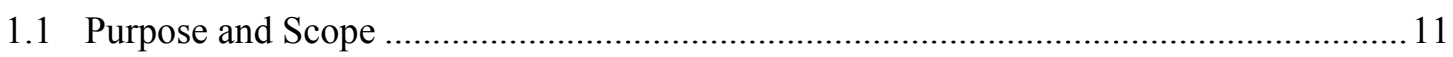

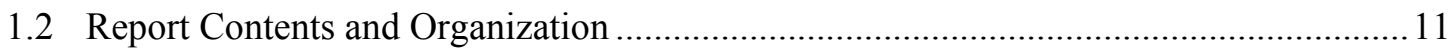

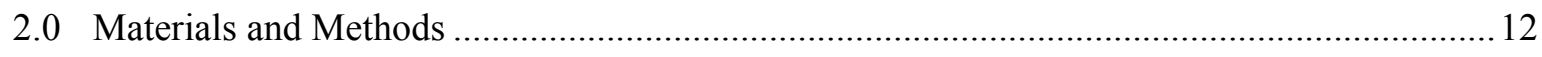

2.1 Specified Concrete Composition for Encasement........................................................ 12

2.1.1 Materials and Laboratory-Scale Mixture Design .............................................. 12

2.2 Concrete Mix and Specimen Preparation ..................................................................... 13

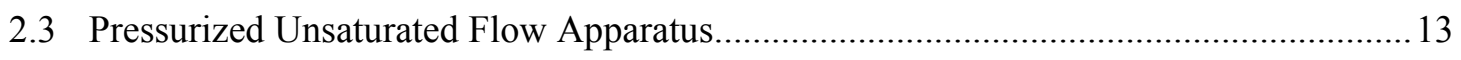

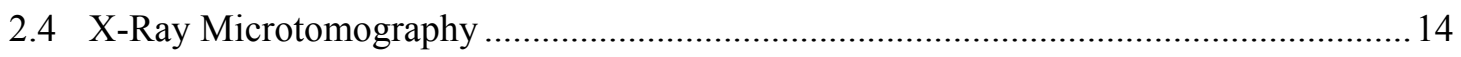

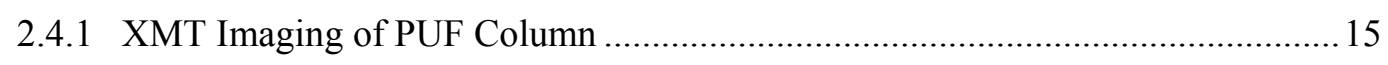

2.4.2 XMT imaging of Concrete Monoliths.................................................................. 15

3.0 Pressurized Unsaturated Flow Tests Selected Concrete Wasteforms to Assess the Long-term Stability under Hanford Site Vadose Zone Conditions ...................................................... 16

4.0 Determination of the Rate of Concrete Carbonation under Simulated Vadose Zone

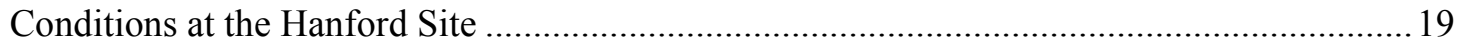

4.1 XMT Visualization of Concrete Monoliths.................................................................. 19

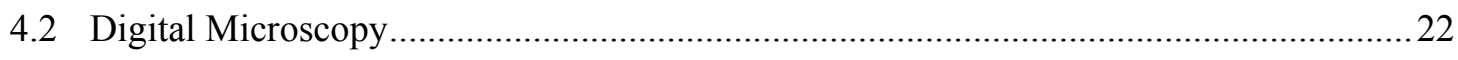

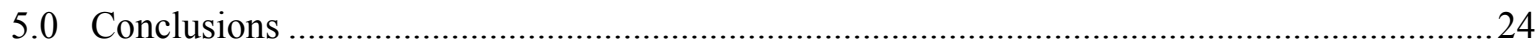

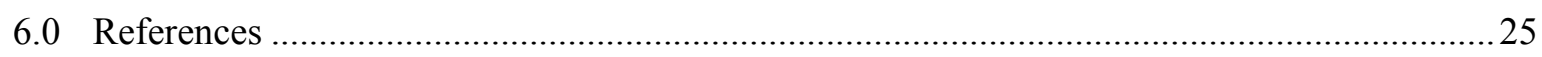




\section{Figures}

2.1. PUF Column Assembly

3.1. $\log _{10}$ Concentration of Elements, in $\mu \mathrm{g} / \mathrm{L}$, Released from the Concrete Coupon PUF

Column Measured in the Effluent Solutions as a Function of Pore Volume ............................. 17

3.2. XMT Image of Packed Concrete PUF Column

4.1. (a) Medium Resolution XMT Image of Concrete Monolith Sample OC-4\%, (b) High Resolution XMT Image of Concrete Monolith Sample OC-4\%

4.2. (a) Medium Resolution XMT Image of Concrete Monolith Sample OC-7\%, (b) High Resolution XMT Image of Concrete Monolith Sample OC-7\%.

4.3. a) Medium Resolution XMT Image of Sample 6-8-6-0-3-4 b) High Resolution XMT Image

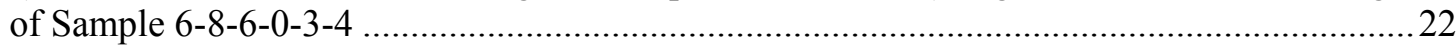

4.4. Sample OC-4\% under 50x magnification, red region indicates region of carbonation ............23

4.5. Sample OC-7\% under 50x magnification, red region indicates region of carbonation .............23

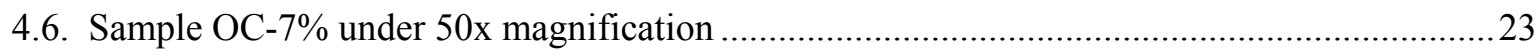




\section{Tables}

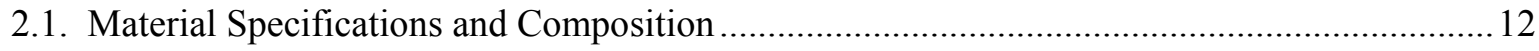

2.2. Laboratory-scale Material Specification and Composition.................................................... 13

4.1. Concrete Monoliths Subject to Carbonation/Micro-cracking Analysis ..................................19 


\subsection{Introduction}

One of the methods being considered for safely disposing of Category 3 low-level radioactive wastes is to encase the waste in concrete. Concrete encasement would contain and isolate the waste packages from the hydrologic environment and would act as an intrusion barrier. The current plan for waste isolation consists of stacking low-level waste packages on a trench floor, surrounding the stacks with reinforced steel, and encasing these packages in concrete. These concrete-encased waste stacks are expected to vary in size with maximum dimensions of $6.4 \mathrm{~m}$ long, $2.7 \mathrm{~m}$ wide, and $4 \mathrm{~m}$ high. The waste stacks are expected to have a surrounding minimum thickness of $15 \mathrm{~cm}$ of concrete encasement and are expected to withstand environmental exposure (solar radiation, temperature variations, and precipitation) until an interim soil cover or permanent closure cover is installed and will remain largely intact thereafter. Any failure of concrete encasement may result in water intrusion and consequent mobilization of radionuclides from the waste packages.

Key contaminants within low-activity and secondary wastes from treatment of the Hanford Site tank wastes include ${ }^{129} \mathrm{I},{ }^{75} \mathrm{Se},{ }^{99} \mathrm{Tc}$, and ${ }^{238} \mathrm{U}$ (Mann et al. 2001; Wood et al. 1995). The geochemistry of porefluids in contact with cementitious materials is characterized by highly alkaline $\mathrm{pH}$ values. Because of their anionic nature in aqueous solutions, ${ }^{129} \mathrm{I},{ }^{75} \mathrm{Se},{ }^{99} \mathrm{Tc}$, and carbonate-complexed ${ }^{238} \mathrm{U}$ may readily leach into the subsurface environment (Serne et al. 1989, 1992, 1993, 1995) by mass flow and/or diffusion and move into the surrounding subsurface environment. Thus, it is critical to understand the 1) speciation and interaction of the radionuclides within the concrete wasteform; 2) diffusion of radionuclide species when contacted with vadose zone porewater or groundwater; and 3) long-term durability and weathering of concrete wasteforms under environmental conditions relevant to the depository.

Although significant research has been conducted on the design and performance of cementitious wasteforms, the current protocol conducted to assess radionuclide stability within these wasteforms has been limited to the Toxicity Characteristic Leaching Procedure, Method 1311 Federal Registry and ANSI/ANS-16.1 leach test (ANSI 1986). These tests evaluate the performance under water-saturated conditions and do not evaluate the performance of cementitious wasteforms within the context of waste depositories that are located in hydraulically unsaturated environments. Moreover, these tests assess only the diffusion of radionuclides from concrete wasteforms and neglect evaluating the mechanisms of retention, stability of the wasteform, and formation of secondary phases during weathering, which may serve as long-term secondary hosts for immobilization of radionuclides.

The results of recent investigations conducted under arid and semi-arid conditions provide valuable information suggesting structural and chemical changes to concrete wasteforms, which may affect contaminant containment and wasteform performance (Al-Khayat et al. 2002; Garrabrants and Kosson 2003, Garrabrants et al. 2002, 2004; Gervais et al. 2004; Sanchez et al. 2002, 2003). A recent review conducted by the National Academies of Science recognized the efficacy of cementitious materials for waste isolation, but further noted the significant short-comings in our current understanding and testing protocol for evaluating the performance of various formulations (National Research Council 2009). Continued research is necessary to understand the following:

- the mechanism of contaminant release, the significance of contaminant release pathways

- how wasteform performance is affected by the full range of environmental conditions within the disposal facility 
- the process of wasteform aging under conditions that are representative of processes occurring in response to changing environmental conditions within the disposal facility

- the effect of wasteform aging on chemical, physical, and radiological properties and the associated impact on contaminant release.

\subsection{Purpose and Scope}

The objective of the investigation reported here is to collect data that 1) quantifies radionuclide retention within concrete wasteform materials similar to those used to encapsulate waste in the low-level burial ground; and 2) measures the effect of concrete wasteform properties likely to influence radionuclide migration.

\subsection{Report Contents and Organization}

The ensuing sections of this report present the results of the concrete-soil half-cell tests, modeling of uranium (VI) solubility in concrete porewaters, single-pass flow-through tests on cementitious wasteforms, and preparation of simulated tank waste concrete half-cell tests.

- Section 2.0 describes the preparation of concrete used in the work

- Section 3.0 describes the set of pressurized unsaturated flow (PUF) experiments initiated during fiscal year (FY) 2009 to determine the long-term stability of concrete wasteforms under unsaturated sediments

- Section 4.0 describes the results from a 6-year study investigating the rate of concrete carbonation under simulated vadose zone conditions at the Hanford Site. 


\subsection{Materials and Methods}

\subsection{Specified Concrete Composition for Encasement}

Table 2.1. Material Specifications and Composition

\begin{tabular}{|c|c|c|c|}
\hline Material & Specifications & $\begin{array}{l}\text { Specified Field } \\
\text { Mix }\end{array}$ & $\begin{array}{c}\text { Normalized } \\
\text { Specification } \\
\text { Design }\end{array}$ \\
\hline Cement & Portland Type I or Type I/II sulfate-resistant cement & $381 \mathrm{~kg} / \mathrm{m}^{3}$ & 0.27 \\
\hline Fly Ash & Class F fly ash; nominal $15 \%$ of cement by volume & $54 \mathrm{~kg} / \mathrm{m}^{3}$ & 0.04 \\
\hline Coarse Aggregate & No. 676 or equivalent ( $3 / 4^{\prime \prime}$ nominal size) & $55 \%$ by volume & 0.04 \\
\hline Fine Aggregate & Sand & $45 \%$ by volume & 0.51 \\
\hline Water & Nominal water:cement ratio: 0.4 & $399 \mathrm{~kg} / \mathrm{m}^{3}$ & 0.10 \\
\hline Steel Fiber & Deformed Type I, nominal length $2.5-3.8 \mathrm{~cm}\left(1-1.5^{\prime \prime}\right)$ & $59 \mathrm{~kg} / \mathrm{m}^{3}$ & 0.04 \\
\hline Air Content & & $6.0 \pm 1.5 \%$ & \\
\hline
\end{tabular}

The concrete composition for the burial encasement was specified in Specification for Concrete Encasement for Contact-Handled Category 3 Waste. ${ }^{1}$ This specification was used as the basis to prepare a concrete for fabrication of test specimens. The composition includes sulfate-resistant Portland Type I or Type II cement, a pozzolanic material (Class F fly ash), fine and coarse aggregates, and steel fiber. Additional specifications include a water-to-cement ratio of 0.4 and an air content $6.0 \pm 1.5 \%$. The nominal proportions and material specifications based on this initial design are listed in Table 2.1.

\subsubsection{Materials and Laboratory-Scale Mixture Design}

A laboratory-scale concrete mixture (Table 2.2) was prepared based on specifications shown in Table 2.1. Because of the required small dimensions of laboratory test specimens, the size of the coarse aggregate and the dimensions of the steel fiber specified in Table 2.1 were proportionately reduced. This was accomplished by decreasing the 2 -cm $(\sim 0.75$-in.) coarse aggregate size in the original specification to a particle size ranging from $2.83 \mathrm{~mm}$ to $2 \mathrm{~mm}$ in the laboratory mix. Aggregate passing a 7-mesh sieve and retained on a 10-mesh sieve met this particle size specification. Iron particles were used in the laboratory mix in place of the steel fibers. Based on these modifications, a concrete mix was prepared that consisted of cement (Type I and II, American Society for Testing and Materials C-150 compliant), Class F fly ash, scaled-down coarse aggregate, fine aggregate, iron particles, and a water-entraining agent (Polyheed 997). The water-entraining agent was included in the mix to facilitate the workability of the concrete. The volumes of the Polyheed 997 and the air-entraining agent, MB AE 90, were not included in the normalization calculations because of their negligible contribution to the overall mix volume. The material specification and composition for the laboratory-scale concrete mixture is given in Table 2.2.

\footnotetext{
1 “Specification for Concrete Encasement for Contact-Handled Category 3 Waste." 1998. Proceedings of Waste Management.
} 
Table 2.2. Laboratory-scale Material Specification and Composition

\begin{tabular}{|c|c|c|c|}
\hline Material & $\begin{array}{l}\text { Material Specifications for } \\
\text { Field Mix }\end{array}$ & $\begin{array}{c}\text { Normalized } \\
\text { Laboratory Design }\end{array}$ & $\begin{array}{c}\text { Material Specifications Used in } \\
\text { Revised Laboratory Mix } \\
\text { Comparison }\end{array}$ \\
\hline Cement & $\begin{array}{l}\text { Portland Type I or Type I/II } \\
\text { sulfate-resistant cement }\end{array}$ & 0.27 & Portland Type I \& II \\
\hline Fly Ash & $\begin{array}{c}\text { Class F fly ash; nominal } 15 \% \text { of } \\
\text { cement by volume }\end{array}$ & 0.04 & $\begin{array}{c}\text { Class F fly ash; nominal } 20 \% \text { of } \\
\text { cement by volume }\end{array}$ \\
\hline $\begin{array}{c}\text { Coarse } \\
\text { Aggregate }\end{array}$ & $\begin{array}{l}\text { No. } 676 \text { or equivalent } \\
\text { (3/4-in. nominal size) }\end{array}$ & 0.04 & $\begin{array}{l}\text { Sieve size }+7 \text { to }-10 \\
(2.83-2 \mathrm{~mm} \text { size })\end{array}$ \\
\hline Fine Aggregate & Sand & 0.51 & Sand -10 sieve size $(<2 \mathrm{~mm})$ \\
\hline Water & Nominal water:cement ratio: 0.4 & 0.10 & Water-to-cement ratio: 0.5 \\
\hline Iron Powder & Iron particles & 0.04 & -200 mesh \\
\hline Polyheed 997 & -- & 0.00375 & Water-entraining agent \\
\hline Air Content & $6.0 \pm 1.5 \%$ & $6.0 \pm 1.5 \%$ & -- \\
\hline
\end{tabular}

\subsection{Concrete Mix and Specimen Preparation}

In general, concrete monoliths were prepared with mix components added in this order: water, steel (if applicable), coarse aggregate, fine aggregate, fly ash, cement, Polyheed 997, and MB AE 90. The concrete was mixed on medium speed using a Hobart three-speed, bench-top mixer in a $4 \mathrm{~L}$ steel bowl. The concrete molds for casting specimens were fabricated from Schedule 40 polyvinyl chloride (PVC) piping material. Gaskets were glued to the bottom of the molds and leak tested before use. The PVC molds were filled in the vertical position. After filling, the molds were lightly tapped on the laboratory bench until a significant decrease in the release of air bubbles was observed. The forms were stored in a humidity chamber for 28 days to provide moisture while the concrete set. The concrete monoliths were subsequently removed from the molds and the respective monoliths were carbonated by soaking for 7 days in a saturated sodium-bicarbonate solution. Specific treatments for concrete monoliths (e.g., carbonation, iron content, contaminant content) used in concrete-sediment half-cell experiments are discussed below within the context of the respective half-cell preparation.

\subsection{Pressurized Unsaturated Flow Apparatus}

Dynamic tests were conducted under unsaturated conditions using the PUF system (McGrail et al. 1997, 1999; Pierce et al. 2006; Wierenga and Van Genuchten 1989). The PUF system allows controlled dynamic changes in water content that simulate the periodic wet-dry cycling experienced in the deep vadose zone and smear zone. Additionally, slight changes in $\mathrm{pH}$, conductivity, and water content that occur during dissolution and precipitation reactions are continuously logged via the PUF system. As such, the PUF system is well suited to conduct unsaturated weathering and precipitation experiments (McGrail et al. 1997, 1999; Pierce et al. 2006) (Figure 2.1). 


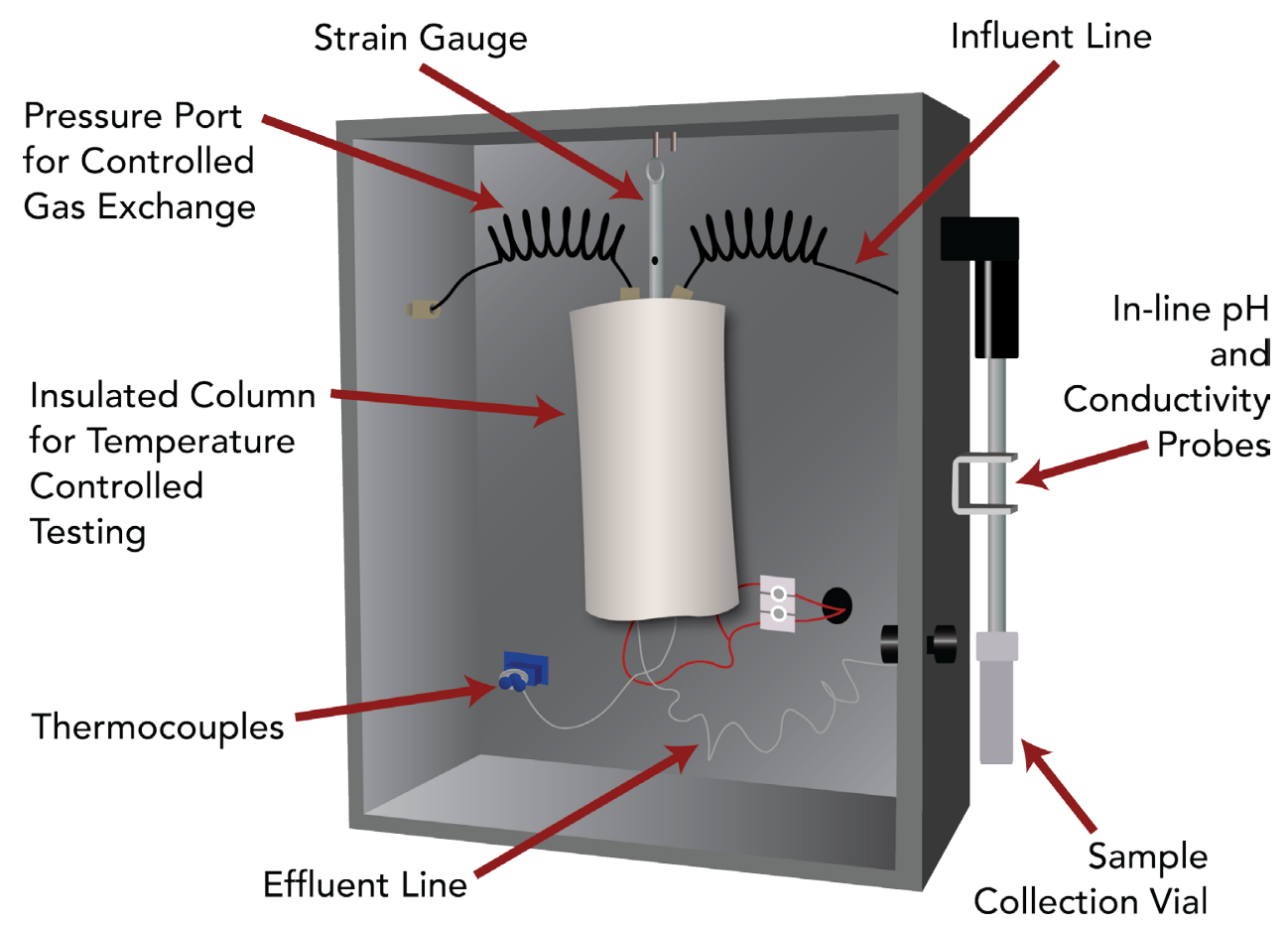

Figure 2.1. PUF Column Assembly

The PUF system, which is similar to a Wierenga column (McGrail et al. 1997, 1999), consists of a polyetheretherketone column $(r=0.96 \mathrm{~cm}, L=7.62 \mathrm{~cm})$ with a porous titanium plate; it has a nominal pore size of $0.2 \mu \mathrm{m}$ and is sealed in the bottom of the column. Once the porous titanium plate is water saturated, water, but not air, is allowed to flow through the $0.2-\mu \mathrm{m}$ pores, as long as the applied pressure differential does not exceed the air entry relief pressure - referred to as the bubble pressure of the Ti-plate. If the pressure differential is exceeded, air will escape through the plate and compromise the capability to maintain unsaturated flow conditions in the column (McGrail et al. 1997, 1999). The PUF test computer control system runs LabVIEW ${ }^{\text {TM }}$ (National Instruments Corporation) software for logging test data from several thermocouples, pressure sensors, inline sensors that measure effluent $\mathrm{pH}$ and conductivity, and from an electronic strain gauge that measures column weight to accurately track water mass balance and saturation level. The column also includes a PUF port, which is an electronically actuated valve that periodically vents the column gases. The purpose of column venting is to prevent reduction in the partial pressure of important gases, especially $\mathrm{O}_{2}$ and $\mathrm{CO}_{2}$, which may be consumed in a variety of chemical reactions.

\subsection{X-Ray Microtomography}

X-ray microtomography (XMT) provides a novel nondestructive imaging technique to characterize concrete samples. XMT is a in which a sample is rotated $360^{\circ}$ around a central axis while two-dimensional $\mathrm{x}$-ray images are collected. The $\mathrm{x}$-ray images are reconstructed to produce a threedimensional representation of the sample volume. The XMT technique produces the equivalent of 'CATscans.' However, the resolution scale of the former is much finer $(\sim 13$ to $103 \mu \mathrm{m})$ compared with the latter. The XMT system consists of a Digital X-ray Imaging and Computed Tomography system manufactured by North Star Imaging, Inc. The X-ray generator was a Fienfocus model $160.48160 \mathrm{kV}$ Microfocus X-ray Unit with a $5 \mu \mathrm{m}$ spot size and 10 to $160 \mathrm{KeV}$ range. A computer-controlled sample 
manipulator with a $75-\mathrm{mm}$ diameter turntable allowed $365^{\circ}$ of continuous rotation and a maximum vertical travel of $150 \mathrm{~mm}$. The X-ray detector was a Varian Paxscan 2520V Amorphous Silicon Cesium Scintillator with an 8 " x 10" image area. The system produced cross-sectional computed tomographic (CT) images and digitized radiographs (DR). A computer data acquisition, instrument control and image reconstruction system with $e f x$-ct software provided X-ray and sample manipulation control in addition to CT and CT Multi-Planer (MPR-3D) imaging.

\subsubsection{XMT Imaging of PUF Column}

X-ray microtomography (XMT) analysis of the PUF column after 120 pore volumes of flow was conducted. Columns were imaged at $102 \mathrm{KeV}$ and $1070 \mu \mathrm{A}$, with 1 image per $0.5^{\circ}$ of rotation or 721 views, at a capture rate of one frame per second. Two stainless steel filters were used to reduce beam hardening and detector saturation. The light field detector calibration was conducted at $267 \mu \mathrm{A}$ and the dark field calibration was conducted with the X-Ray tube deactivated.

Two-dimensional reconstruction and three-dimensional volume rendering were conducted using efxct image reconstruction software. Additional advanced visualization was performed using AVIZO® Fire 6.0 image processing software. Two-dimensional slices were loaded into the AVIZO® Fire module and displayed using the voltex visualization package. Image resolution of the reconstructed column was 17 $\mu \mathrm{m} /$ pixel.

\subsubsection{XMT imaging of Concrete Monoliths}

Full concrete cores and subsections were imaged individually using medium and high resolution scans, to evaluate the depth of carbonation. The full concrete monoliths were imaged at $100 \mathrm{KeV}$ and $1012 \mu \mathrm{A}$, with 1 image per $0.5^{\circ}$ of rotation or 721 views, at a capture rate of two frames per second. One stainless steel filter was used to reduce background image intensity and reduce detector saturation. The light field detector calibration was conducted at $253 \mu \mathrm{A}$ and the dark field calibration was conducted with the X-Ray tube deactivated. The image resolution of the reconstructed monoliths was $102 \mu \mathrm{m} / \mathrm{pixel}$.

Subsections of the concrete monoliths were cut using a precision slow speed diamond blade saw. The smaller samples of the outer monolith edge were imaged at $48 \mathrm{KeV}$ and $1032 \mu \mathrm{A}$, with 1 image per $0.5^{\circ}$ of rotation or 721 views, at a capture rate of one frames per second. One four layer aluminum filter was used to reduce beam hardening and detector saturation. The light field detector calibration was conducted at $258 \mu \mathrm{A}$ and the dark field calibration was conducted with the X-Ray tube deactivated. The image resolution of the sectioned reconstructed monoliths was $13 \mu \mathrm{m} /$ pixel.

As indicated prior, two-dimensional reconstruction and three-dimensional volume rendering were conducted using efx-ct image reconstruction software. Two-dimensional slices were loaded into the AVIZO ${ }^{\circledR}$ Fire module and displayed using the orthoslice module. 


\subsection{Pressurized Unsaturated Flow Tests Selected Concrete Wasteforms to Assess the Long-term Stability under Hanford Site Vadose Zone Conditions}

The long-term stability of materials is controlled by solubility and the rate of dissolution. Under highly advective conditions where the rate of transport is greater than the solubility rate, the stability of the material is controlled by dissolution kinetics. Alternatively, in low to moderately advective environments where the solubility is greater than the rate of mass transport, the long-term stability of the material is based on the solubility of the phase. Complex wasteforms, such as concrete exposed to environmental conditions may exhibit complex, integrated weathering processes that include dissolution and precipitation of the wasteform itself and the secondary phases that form during reaction. Therefore, to accurately predict the long-term stability of concrete wasteforms under relevant environmental conditions, the rate of wasteform weathering and formation of secondary phases and the identity of relevant secondary phases and their impact on contaminant retention must be known.

In FY 2009, a PUF column was packed with concrete coupons and quartz sand, to be run at $23^{\circ} \mathrm{C}$. The columns were saturated from the bottom using vacuum pressure and a flow rate of $10 \mathrm{~mL} / \mathrm{hr}$. The process of fully saturating the column and reducing the water content to the desired level minimizes preferential flow paths and hysteresis verifies the most consistent, uniform attainment of water content within a series of unsaturated columns, and affords a consistent method for establishing unsaturated conditions. Sediment bulk density, $\rho_{b}\left(\mathrm{~g} \mathrm{~cm}^{-3}\right)$, and volumetric water content, $\theta\left(\mathrm{cm} \mathrm{cm}^{-3}\right)$, were determined from the mass of the sediment and water. The percent saturation was calculated from the ratio of the volumetric water content to the total porosity, $\phi$, which was calculated from the bulk density and particle density, $\rho_{p}\left(\mathrm{~g} \mathrm{~cm}^{3}\right)$.

Flow was initiated with Hanford Site groundwater at a rate of $2 \mathrm{~mL} /$ day under a pressure of 2 psi. All effluent solutions were monitored for $\mathrm{pH}$ with inline sensors. Prior to starting the experiments, the in-line $\mathrm{pH}$ probe was calibrated with National Bureau of Standards $\mathrm{pH}$ buffers $(\mathrm{pH} 7.00,10.00$, or 12.00 at $25^{\circ} \mathrm{C}$ ). Precision of $\mathrm{pH}$ measurement was $\pm 0.02 \mathrm{pH}$ units. Concentrations of $\mathrm{Ca}, \mathrm{K}, \mathrm{Na}, \mathrm{Re}$, and $\mathrm{Si}$ in the effluent solutions samples were monitored with ICP-OES. After passing through the $0.2-\mu \mathrm{m}$ Ti porous plate and the inline sensors, aliquots of the effluent solutions were acidified with ultra-high-purity concentrated $\mathrm{HNO}_{3}$ and analyzed using inductively coupled plasma optical emission spectrometry (ICP-OES).

Results to date for the PUF column containing concrete monoliths in quartz sand at $23^{\circ} \mathrm{C}$ are presented in Figure 3.1. Results from the analyses of effluent samples of $\mathrm{Ca}, \mathrm{Si}$, and $\mathrm{Na}$ are relatively constant over the duration of the experiment thus far. The $\mathrm{Ca}$ concentration reached a steady concentration of $3.3 \times 10^{4} \mu \mathrm{g} / \mathrm{L}$ after 20 pore volumes. The silicon concentration reached a steady state of $1.5 \times 10^{4} \mu \mathrm{g} / \mathrm{L}$ after 12 pore volumes of flow. Concentrations of Re initiated at $3.32 \times 10^{7} \mu \mathrm{g} / \mathrm{L}$ and steadily declined to $3.6 \times 10^{3} \mu \mathrm{g} / \mathrm{L}$ over 90 pore volumes. The Re concentration then dropped below detection limits. The Na concentration started at $1.5 \times 10^{8}$ and decreased to $3.26 \times 10^{4}$ after 40 pore volumes. It increased slightly between 40 and 60 pore volumes to $\sim 8.6 \times 10^{4} \mu \mathrm{g} / \mathrm{L}$ before decreasing to $2.1 \times 10^{4} \mu \mathrm{g} / \mathrm{L}$ at 107 pore volumes of flow; it thereafter remained steady. The $\mathrm{K}$ concentrations varied between $2.96 \mathrm{x}$ $10^{4}$ and $9.24 \times 10^{5} \mu \mathrm{g} / \mathrm{L}$ over the duration of the experiment without stabilizing. 

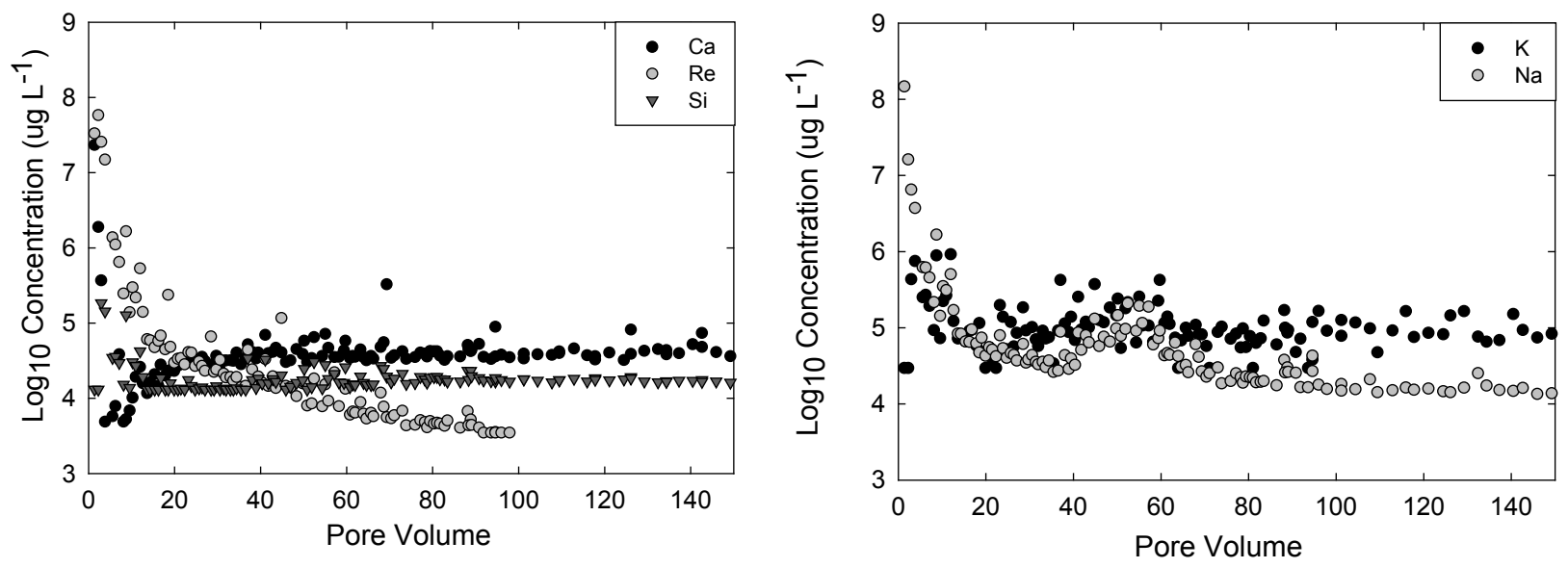

Figure 3.1. $\log _{10}$ Concentration of Elements, in $\mu \mathrm{g} / \mathrm{L}$, Released from the Concrete Coupon PUF Column Measured in the Effluent Solutions as a Function of Pore Volume

Figure 3.2 displays an XMT image of the PUF column packed with concrete monoliths and quartz sand. XMT analysis and image processing indicate no change in X-ray attenuation on the edges of the concrete coupons. This suggests that there have been little morphological change to the coupons after $\sim 2$ years. The lighter points observable on the coupons are due to a high attenuation of the X-rays, which highlight the location of the iron particles within the concrete monoliths.

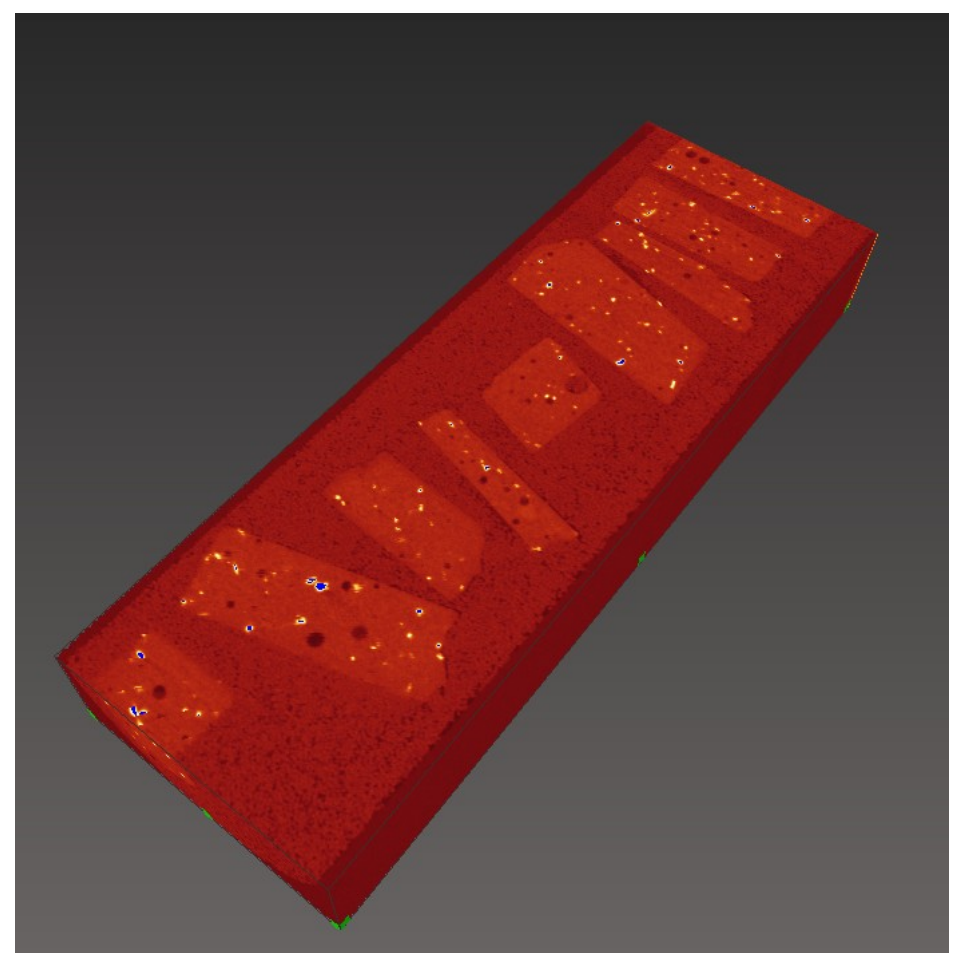

Figure 3.2. XMT Image of Packed Concrete PUF Column 
The results of effluent concentration data and image analysis by XMT indicate the concrete coupons have remained largely nonreactive for more than two years. As such, the PUF column was not terminated and continues to run under the noted test conditions. Monitoring of the PUF column will continue until an agreed upon time. 


\subsection{Determination of the Rate of Concrete Carbonation under Simulated Vadose Zone Conditions at the Hanford Site}

It is known that carbonation and microcracking of weathering concrete waste forms affects the leachability and diffusivity of contaminant species. To study the rate of carbonation and concomitant microcrack development, a set of experiments was conducted that consisted of aging concrete specimens encased in Hanford sediments ( $4 \%$ and $7 \%$ moisture content by weight) in a sealed chamber. The specimens were aged for periods of time ranging from 6 months to 6 years. Previous results documented that after aging for 6 months, the concrete specimens showed minimal carbonation and no detectable microcracking. The concrete specimens removed after one year of aging showed carbonation only in the surface region of each specimen. The maximum depth of carbonation was approximately $1.5 \mathrm{~mm}$ in the concrete specimen that was encased in soil with $15 \%$ moisture content. Microcracks and adhesion cracks (i.e. cracks along the paste-aggregate contacts within the concrete matrix) were observed relatively frequently in the concrete specimen encased in $15 \%$ moisture content sediment. However, both concrete specimens in contact with sediments at $4 \%$ and $7 \%$ moisture content contained mainly adhesion cracks, and this type of cracking was relatively more common in the specimen in contact with $7 \%$ content.

Results presented here report on the three concrete monoliths that were subjected to XMT analysis and digital microscopy after 6 years storage in simulated vadose zone conditions (Table 4.1).

Table 4.1. Concrete Monoliths Subject to Carbonation/Micro-cracking Analysis

\begin{tabular}{ccc}
\hline Core ID & $\begin{array}{c}\text { Moisture } \\
\text { Content }\end{array}$ & $\begin{array}{c}\text { Experimental } \\
\text { Time }\end{array}$ \\
\hline OC-4\% & $4.00 \%$ & 6 years \\
OC-7\% & $7.00 \%$ & 6 years \\
$6-8-6-0-3-4$ & $7.00 \%$ & 3 years \\
\hline
\end{tabular}

\subsection{XMT Visualization of Concrete Monoliths}

Results from medium resolution XMT analysis indicate minimal morphological change. Figure 4.1 presents medium and high resolution scans of sample OC-4\%. The medium resolution scan, 103 $\mu \mathrm{m} /$ pixel, shows the full sample (Figure 4.1a), with a thin rind of higher density material around the outside of the samples. The region of increased attenuation appears to cover the outermost $400 \mu \mathrm{m}$ or 4 pixels. Higher resolution scans, conducted on a subsection of the original core (Figure 4.1b) indicate the region of higher attenuation penetrates up to $350 \mu \mathrm{m}$. Figure 4.2 presents medium and high resolution scans of sample OC-7\%. The medium resolution scan (Figure 4.2a) also shows a region of higher contrast material around the outside of sample OC-7\%. Higher resolution scans, (Figure 4.2b) indicate the region of higher attenuation penetrates up to $400 \mu \mathrm{m}$, which suggest the zone of penetration is deeper in sample OC-7\% than sample OC-4\%. In both high resolution samples, the zone of increased attenuation is only seen across the curved edge, which supports the conclusion of carbonation. Figure 4.3 presents medium and high resolution images of Sample 6-8-6-0-3-4, which did not exhibit increased attenuation at the edge of the monolith. The absence of a high attenuation rind suggests indicates minimal to no carbonation. 


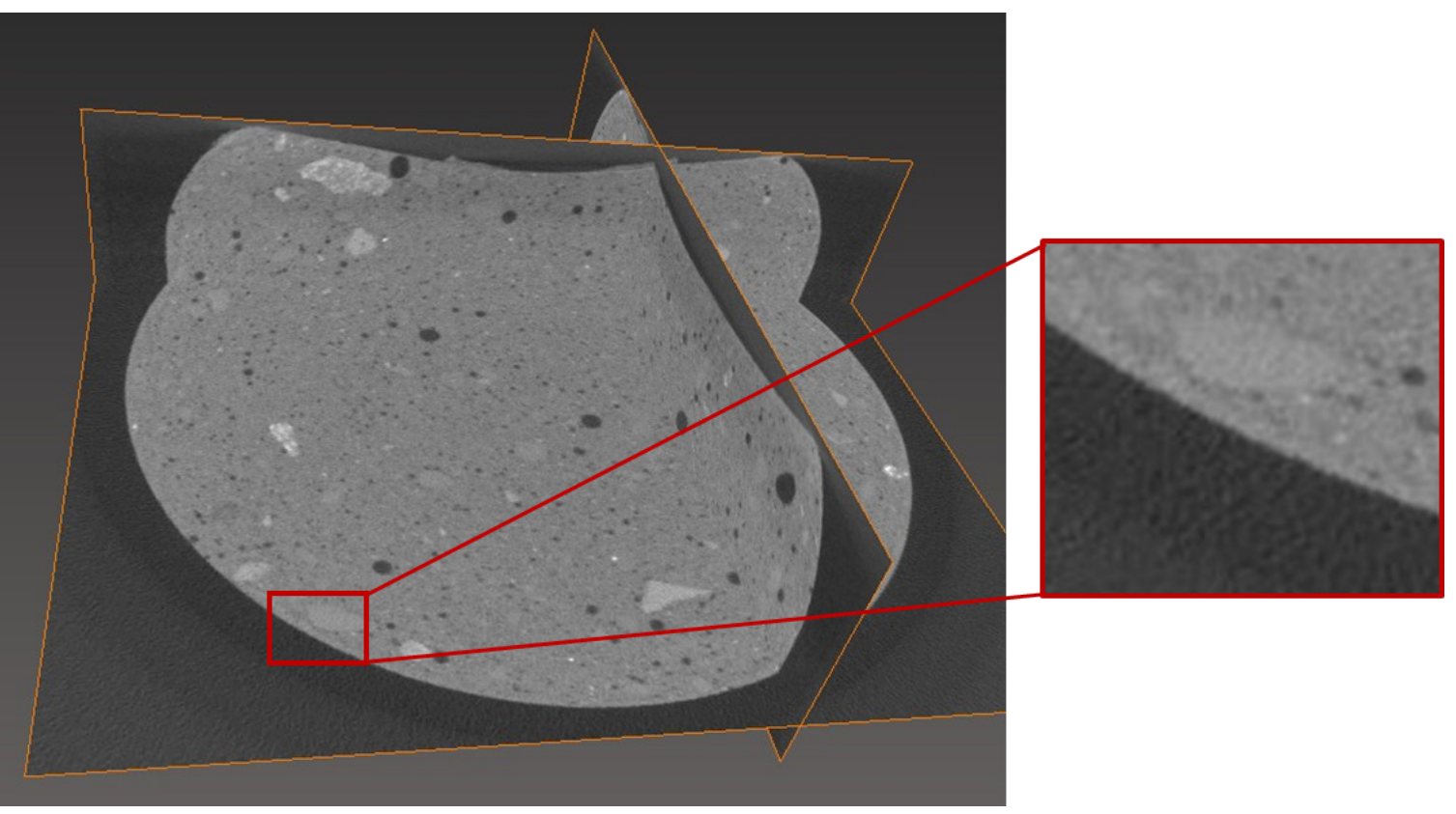

b)
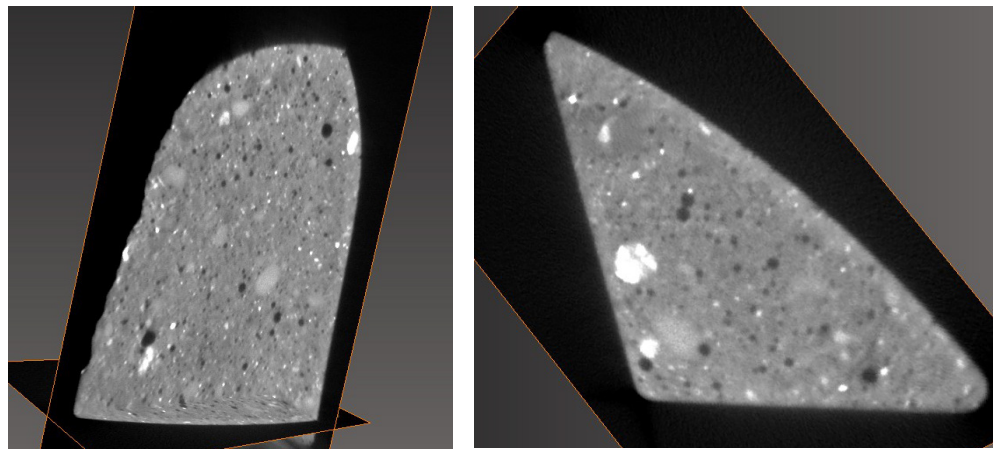

Figure 4.1. (a) Medium Resolution XMT Image of Concrete Monolith Sample OC-4\%, (b) High Resolution XMT Image of Concrete Monolith Sample OC-4\% 


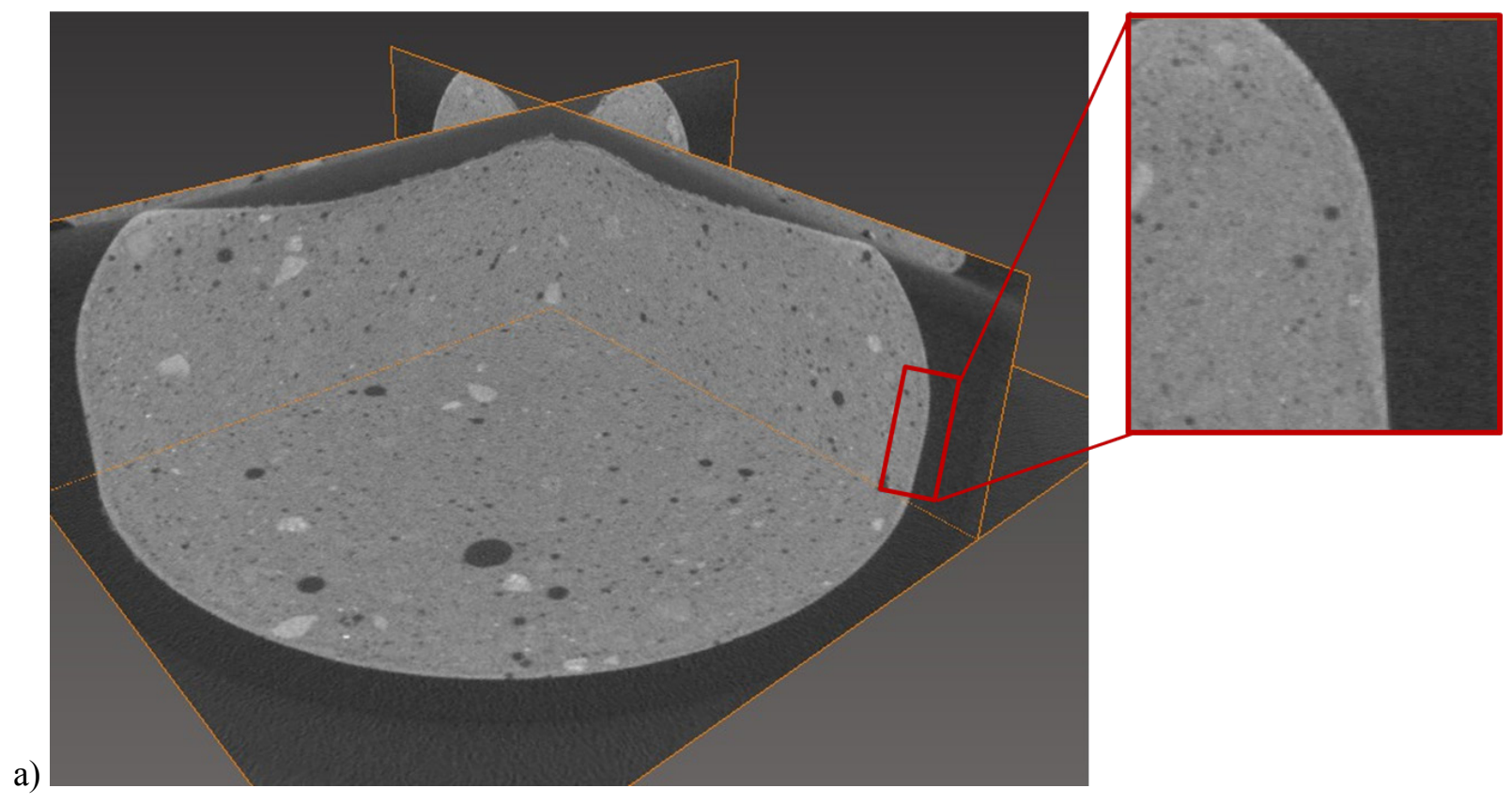

b)
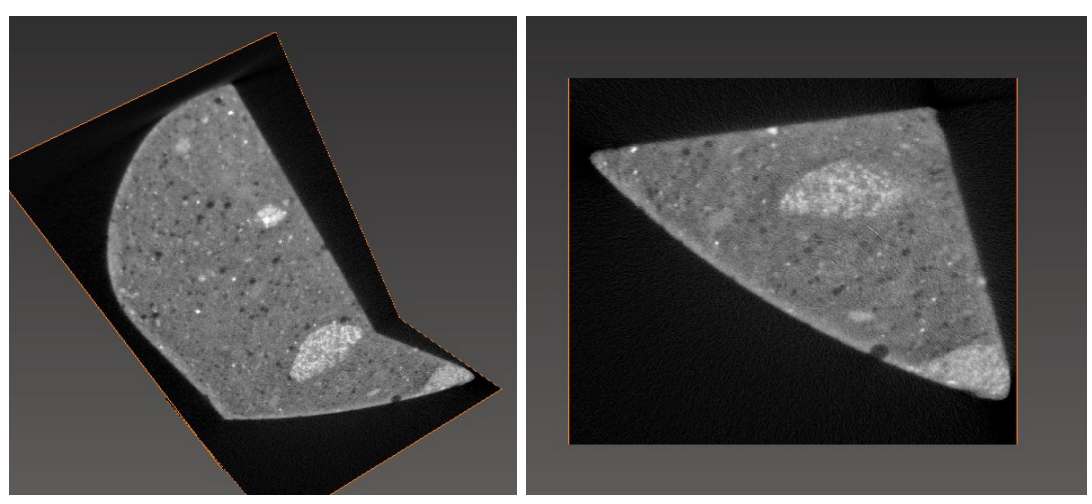

Figure 4.2. (a) Medium Resolution XMT Image of Concrete Monolith Sample OC-7\%, (b) High Resolution XMT Image of Concrete Monolith Sample OC-7\% 


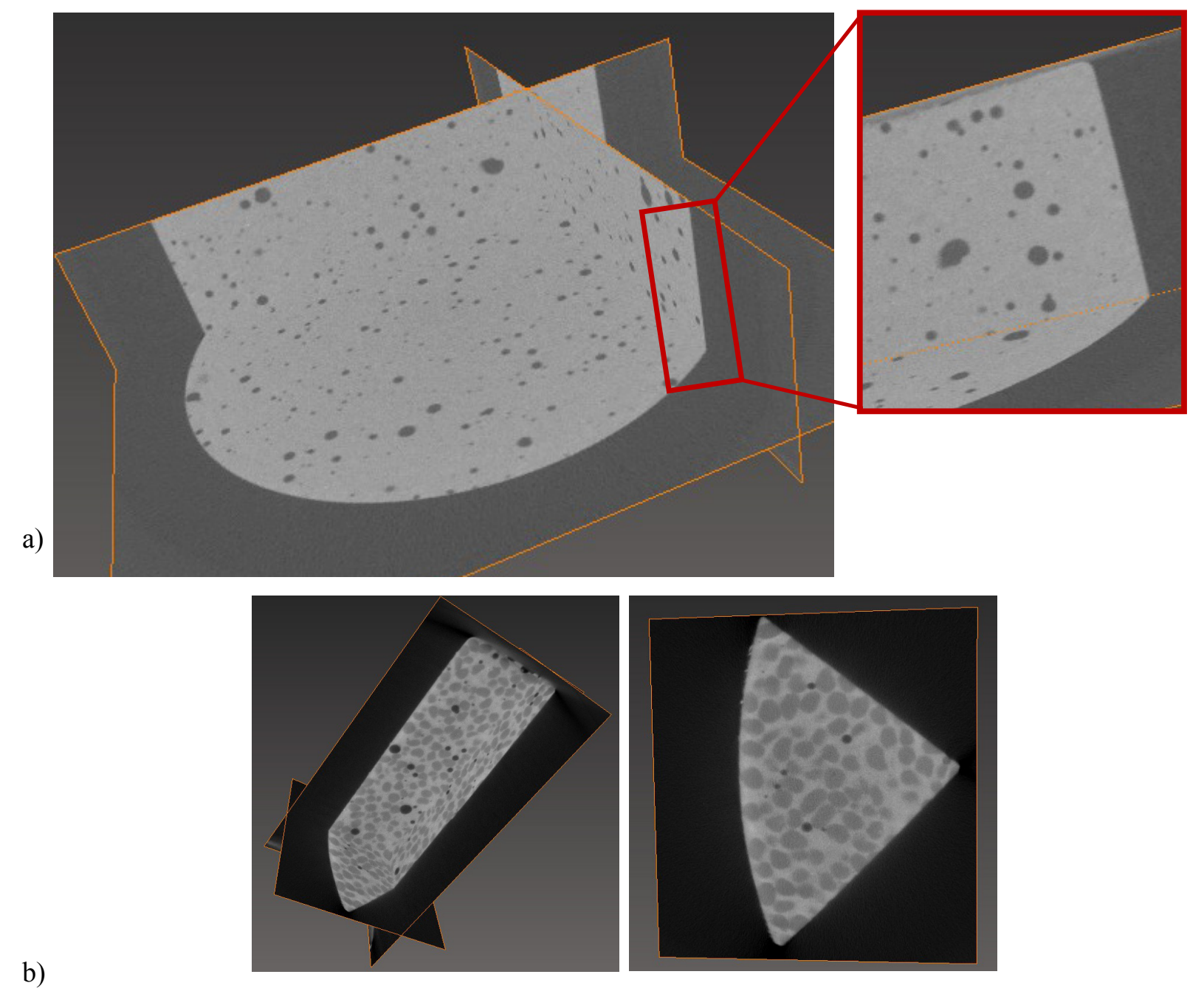

Figure 4.3. a) Medium Resolution XMT Image of Sample 6-8-6-0-3-4 b) High Resolution XMT Image of Sample 6-8-6-0-3-4

\subsection{Digital Microscopy}

Additional evaluation of carbonation and micro-cracking was conducted using digital microscopy. Prepared samples were evaluated under reflected light at 50x magnification. Images captured a region of alteration around the edge of samples OC-4\% (Figure 4.4) and OC-7\% (Figure 4.5), which likely corresponds to carbonation. No alteration was observed on Sample 6-8-6-0-3-4 (Figure 4.6). None of the samples evaluated showed an indication of micro-cracking. 


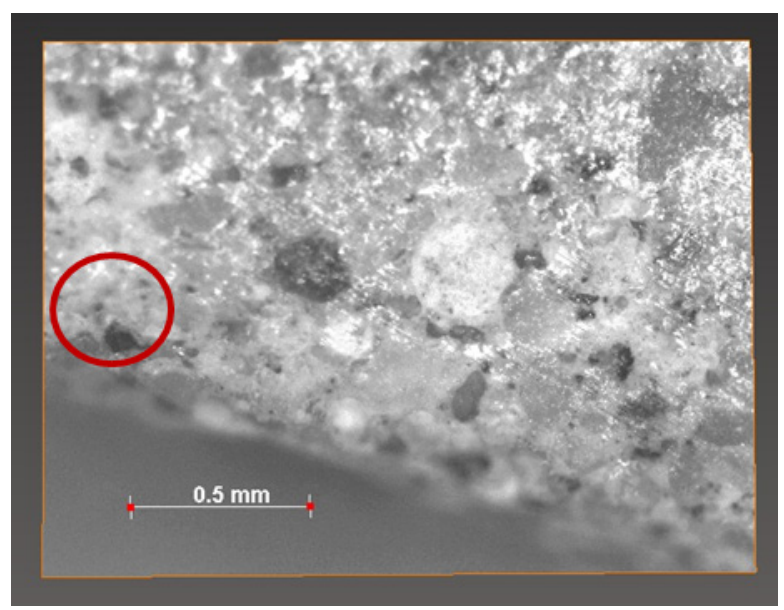

Figure 4.4. Sample OC-4\% under 50x magnification, red region indicates region of carbonation

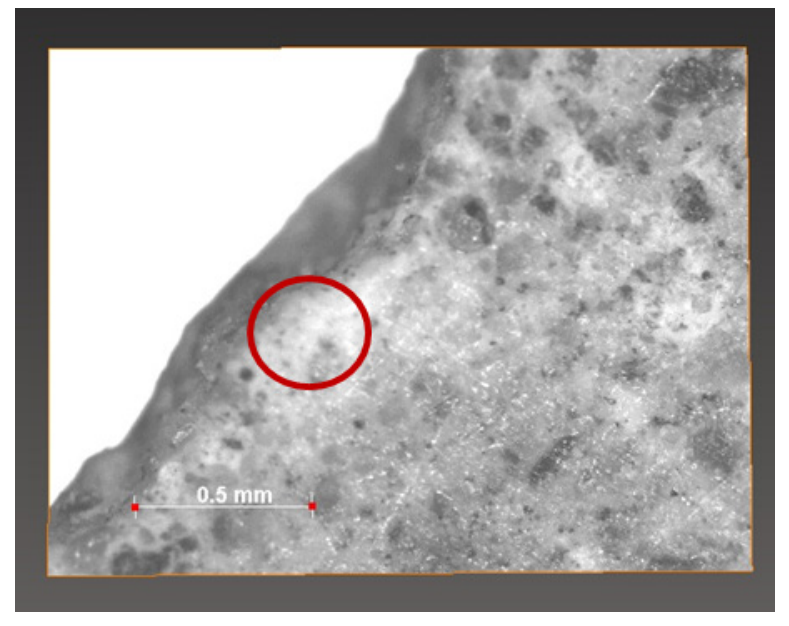

Figure 4.5. Sample OC-7\% under 50x magnification, red region indicates region of carbonation

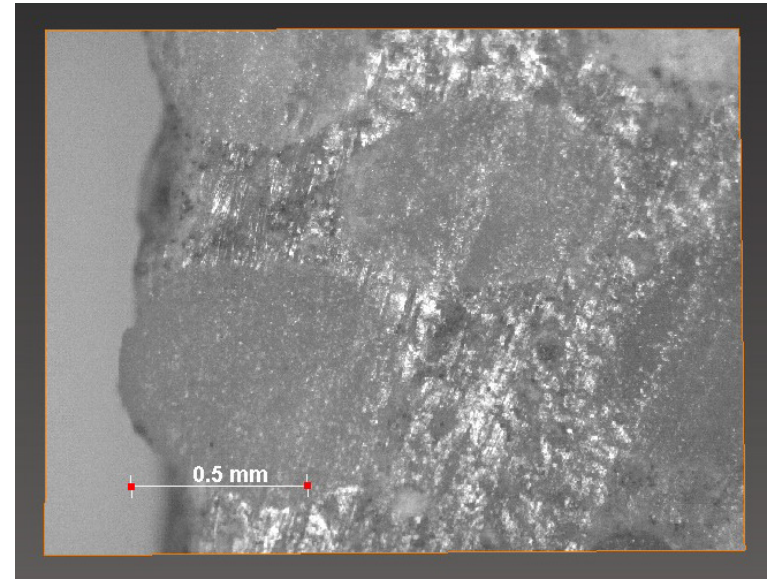

Figure 4.6. Sample OC-7\% under 50x magnification 


\subsection{Conclusions}

The objective of the investigation was to evaluate and quantify 1) radionuclide retention within concrete wasteform materials similar to those used to encapsulate waste in the low-level burial ground and 2) quantifies the rate of carbonation of concrete materials in a simulated vadose zone repository.

Experimental results from column and XMT studies indicate concrete wasteforms reacted with groundwater under unsaturated repository conditions have remained largely nonreactive for more than two years. Therefore, monitoring of the PUF column has not been discontinued.

Three concrete monoliths that had been buried in sediment at $4 \%$ and $7 \%$ moisture content for six years were subjected to XMT analysis and digital microscopy in an effort to evaluate the extent of carbonation of concrete under simulated vadose zone conditions. Carbonation was observed in samples OC- $4 \%$ and OC-7\% to a depth of $400 \mu \mathrm{m}$. No carbonation was observed in Sample 6-8-6-0-3-4. The differences in the extent of carbonation is likely due to differences in the duration of exposure between the OC-4\% and OC-7\% samples, which have been weathered for 6 years and Sample 6-8-6-0-3-4 which was weathered for 3 years. 


\subsection{References}

AlKhayat H, MN Haque, and NJ Fattuhi. 2002. "Concrete Carbonation in Arid Climate." Materials and Structures 35(7):421-426. DOI:10.1007/BF02483146.

ANSI/ANS-American National Standards Institute/American Nuclear Society. Measurement of the Leachability of Solidified Low-Level Radioactive Wastes Short-Term Test Procedure. The American Nuclear Society, Chicago, Illinois.

ASTM C856. 2011. Standard Practice for Petrographic Examination of Hardened Concrete. ASTM International, West Conshohocken, Pennsylvania.

Garrabrants AC and DS Kosson. 2003. "Modeling Moisture Transport from a Portland Cement-based Material during Storage in Reactive and Inert Atmospheres.” Drying Technology 21(5):775-805. DOI:10.1081/DRT-120021686.

Garrabrants AC, F Sanchez, C Gervais, P Moszkowicz, and DS Kosson. 2002. "The Effect of Storage in an Inert Atmosphere on the Release of Inorganic Constituents during Intermittent Wetting of a Cementbased Material." Journal of Hazardous Materials 91(1-3):159-185. DOI:10.1016/S03043894(01)00383-1.

Garrabrants AC, F Sanchez, and DS Kosson. 2004. "Changes in Constituent Equilibrium Leaching and Pore Water Characteristics of a Portland Cement Mortar as a Result of Carbonation." Waste Management 24(1):19-36. DOI:10.1016/S0956-053X(03)00135-1.

Gervais C, AC Garrabrants, F Sanchez, R Barna, P Moszkowicz, and DS Kosson. 2004. "The Effects of Carbonation and Drying during Intermittent Leaching on the Release of Inorganic Constituents from a Cement-based Matrix." Cement and Concrete Research 34(1):119-131. DOI:10.1016/S00088846(03)00248-5.

Mann FM, RJ Puigh II, SH Finfrock, EJ Freeman Jr, R Khaleel, DH Bacon, MP Bergeron, BP McGrail, and SK Wurstner. 2001. Hanford Immobilized Low-Activity Waste Performance Assessment: 2001 Version. DOE/ORP-2000-24, Rev. 0., U.S. Department of Energy, Office of River Protection, Richland, Washington. Available online at: http://www.hanford.gov/docs/gpp/fieldwork/ilaw/ORP 2000_24.pdf.

McGrail BP, PFC Martin, and CW Lindenmeier. 1997. "Accelerated Testing of Waste Forms using a Novel Pressurized Unsaturated Flow (PUF) Method.” In: Proceedings of the 2996 MRS Fall Meeting, December 2-6, 1996, Boston, Massachusetts. Materials Research Society Symposium Proceedings 465:253-260.

McGrail BP, PFC Martin, and CW Lindenmeier. 1999. Method and Apparatus for Measuring Coupled Flow, Transport, and Reaction Processes under Liquid Unsaturated Flow Conditions. U.S. Patent $5,974,859$.

National Research Council. 2009. Advice on the Department of Energy's Cleanup Technology Roadmap: Gaps and Bridges. National Academy Press, Washington, D.C. 
Pierce EM, BP McGrail, MM Valenta, and DM Strachan. 2006. "The Accelerated Weathering of a Radioactive Low-Activity Waste Glass Under Hydraulically Unsaturated Conditions: Experimental Results from a Pressurized Unsaturated Flow Test." Nuclear Technology 155(2):149-155.

Sanchez F, AC Garrabrants, and DS Kosson. 2003. "Effects of Intermittent Wetting on Concentration Profiles and Release from a Cement-based Waste Matrix." Environmental Engineering Science 20(2): 135-153. DOI:10.1089/109287503763336575.

Sanchez F, C Gervais, AC Garrabrants, R Barna, and DS Kosson. 2002. "Leaching of Inorganic Contaminants from Cement-based Waste Materials as a Result of Carbonation during Intermittent Wetting.” Waste Management 22(2):249-260. DOI:10.1016/S0956-053X(01)00076-9.

Serne RJ, VL LeGore, KJ Cantrell, CW Lindenmeier, JA Campbell, and JE Amonette. 1993. Solid-waste Leach Characteristics and Contaminant-sediment Interactions Volume 1: Batch Leach and Adsorption Tests and Sediment Characterization. PNL-8889-Vol.1, Pacific Northwest Laboratory, Richland, Washington.

Serne RJ, RO Lokken, and LJ Criscenti. 1992. "Characterization of Grouted Low-Level Waste to Support Performance Assessment.” Waste Management 12(2-3):271-287. DOI:10.1016/0956053X(92)90054-M.

Serne RJ, WJ Martin, and VL Legore. 1995. Leach Test of Cladding Removal Waste Grout Using Hanford Groundwater. PNL-10745, Pacific Northwest Laboratory, Richland, Washington.

Serne RJ, WJ Martin. VL Legore, CW Lindenmeier, SB McLaurine, PFC Martin, and RO Lokken. 1989. Leach Tests on Grouts Made with Actual and Trace Metal-Spiked Synthetic Phosphate/Sulfate Waste. PNL-7121, Pacific Northwest Laboratory, Richland, Washington.

Wierenga PJ and MT Van Genuchten. 1989. "Solute Transport through Small and Large Unsaturated Soil Columns." Ground Water 27(1): 35-42. DOI: 10.1111/j.1745-6584.1989.tb00005.x.

Wood MI, R Khaleel, PD Rittman, AH Lu, S Finfrock, RJ Serne, and KJ Cantrell. 1995. Performance Assessment for the Disposal of Low-Level Waste in the 218-W-5 Burial Ground. WHC-EP-0645, Westinghouse Hanford Company, Richland, Washington. 



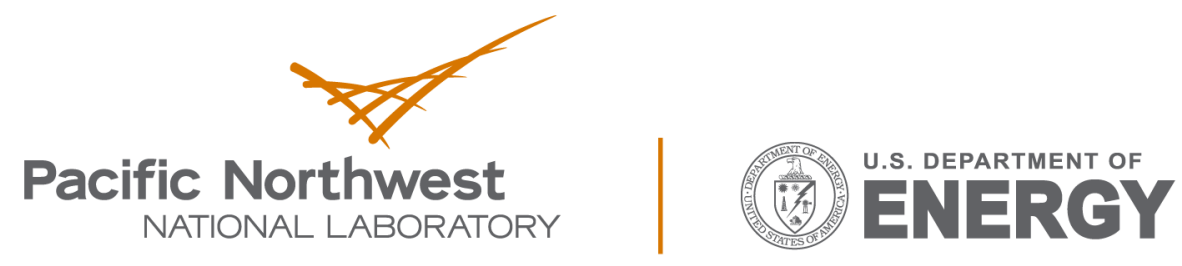

Proudly Operated by Battelle Since 1965

902 Battelle Boulevard

P.O. Box 999

Richland, WA 99352

1-888-375-PNNL (7665)

www.pnnl.gov 